\title{
EFEKTIVITAS PEMBELAJARAN DARING DALAM MENINGKATKAN HASIL BELAJAR PPKN
}

\section{THE EFFECTIVENESS OF ONLINE LEARNING IN IMPROVING PPKN LEARNING OUTCOMES}

\author{
Ibnu Hajar ${ }^{1)}$, Andi Sugiati ${ }^{2)}$, Rismawati ${ }^{3)}$, Gatta ${ }^{4}$ \\ 1,2,3)Universitas Muhammadiyah Makassar, 4)SMP Negeri 1 Gilireng

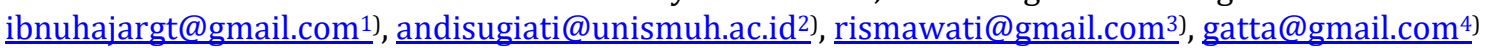

\begin{abstract}
Abstrak
Penelitian ini bertujuan untuk mengetahui efektivitas pembelajaran daring dalam meningkatkan hasil belajar PPKn pada siswa kelas VII SMP Negeri 1 Gilireng. Penelitian ini adalah jenis penelitian kuantitatif deskriptif. Adapun Populasi dalam penelitian ini yakni seluruh peserta didik kelas VII SMP Negeri 1 Gilireng yang berjumlah 87 peserta didik, sedangkan sampel pada penelitian ini sebanyak 43 peserta didik kelas VII SMP Negeri 1 Gilireng yang terpilih dengan menggunakan teknik pengambilan sampel yakni random sampling. Instrumen penelitian yang digunakan yaitu: dokumen, angket (kuesioner), dan pedoman wawancara. Analisis data dalam penelitian ini dilakukan dengan metode kuantitatif deskriptif. Hasil belajar siswa dari 43 siswa, jumlah siswa yang mendapatkan nilai kategori tinggi hanya 7 orang dan siswa yang mendapatkan nilai kategori sedang sebanyak 36 orang. Jumlah siswa pada kategori sedang dan tinggi tersebut tersebar dengan kuantitas yang sama hampir sama dalam menilai efektif dengan tidak efektif pembelajaran daring. Dapat disimpulkan bahwa pembelajaran daring dinilai efektif khususnya bagi yang memiliki hasil belajar yang tinggi dan dapat meningkatkan hasil belajar meskipun banyak kendala yang dialami oleh siswa.
\end{abstract}

Kata Kunci: pembelajaran daring, hasil belajar, PPKn

\begin{abstract}
This study aims to find out the effectiveness of online learning in improving the learning outcomes of PPKn in grade VII students of SMP Negeri 1 Gilireng. This research is a type of descriptive quantitative research. The population in this study is all students in class VIIa, VIIb and VIIC in SMP Negeri 1 Gilireng which amounted to 87 students, while the sample s in this study as many as 43 students of grade VII SMP Negeri 1 Gilireng were selected using sampling techniques, namely random sampling. The research instruments used are: documents, questionnaires, and interview guidelines. The data analysis in this study was conducted by descriptive quantitative method. The results of the students' study from 43 students, the number of students who get high category grades only 7 people and students who get a moderate category score of 36 people. The number of students in the medium and high categories is spread with almost the same quantity in assessing the effectiveness of online learning. It can be concluded that online learning is considered effective especially for those who have high learning outcomes and can improve learning outcomes despite the many obstacles experienced by students.
\end{abstract}

Keywords: online learning, learning outcomes, PPKn 
How to Cite: Hajar, I., Sugiati, A., Rismawati, Gatta. (2021). Efektivitas pembelajaran daring dalam meningkatkan hasil belajar PPKn. Al asma: Journal of Islamic Education, 3(1), 110120.

\section{PENDAHULUAN}

Saat ini pandemi covid-19 atau corona menjadi pembicaraan yang hangat. Di belahan bumi manapun, corona masih mendominasi ruang publik. Covid-19 adalah penyakit menular yang disebabkan oleh jenis corona virus yang baru ditemukan. Virus corona ini bisa menyebabkan ganguan ringan pada sistem pernapasan, infeksi paru-paru yang berat, hingga kematian. Pandemi Covid-19 merupakan masalah multidimensi yang dihadapi dunia, dan dampaknya sangat terasa di bidang pendidikan yang menyebabkan menurunnya kualitas pembelajaran (Sahu, 2020).

Kebijakan baru yang terjadi pada dunia pendidikan telah mengubah pembelajaran yang harus datang ke kelas menjadi cukup dilakukan di rumah saja melalui jaringan internet atau dalam jaringan atau daring (Khasanah, Pramudibyanto, \& Widuroyekt, 2020). Sistem pembelajaran daring dilaksanakan melalui perangkat Personal Computer (PC) atau laptop yang terhubung dengan koneksi jaringan internet. Guru dapat melakukan pembelajaran bersama di waktu yang sama menggunakan grup di media sosial seperti WhatsApp (WA), aplikasi zoom, google meet, ataupun media lainnya sebagai media pembelajaran.

Menurut Mustofa, Chodzirin, Sayekti, dan Fauzan (2019) pembelajaran daring merupakan sistem pembelajaran jarak jauh dengan rangkaian metode pengajaran, dimana kegiatan belajar mengajarnya dilakukan secara terpisah. Pembelajaran daring dilakukan melalui jaringan internet dan Web 2.0 (Alessandro, 2018), yang berarti bahwa penggunaan pembelajaran online melibatkan unsur teknologi sebagai sarana dan jaringan sebagai sistem (Fitriyani, Fauzi, dan Sari, 2020).

Perpindahan sistem belajar konvensional ke sistem daring yang di awal pandemi cukup mendadak, tanpa persiapan yang matang. Hal tersebut menimbulkan ketidaksiapan siswa dan guru terhadap pembelajaran daring. Tetapi tetap dilaksanakan agar proses pembelajaran dapat berjalan lancar dan siswa aktif mengikuti walaupun dalam kondisi pandemi Covid-19.

Hasil observasi yang dilakukan pada guru mata pelajaran PPKn di SMP Negeri 1 Gilireng menunjukkan guru belum mampu menggunakan semua aplikasi pembelajaran daring. Begitu juga dengan masih banyaknya juga peserta didik yang belum terbiasa menggunakan teknologi dalam kehidupan sehari-harinya misalnya handphone karena orangtuanya pun juga tidak memilikinya. Terlihat siswa yang tidak memiliki handphone untuk menunjang kegiatan pembelajaran daring ini merasa kebingungan. Pihak sekolah telah mencari solusi untuk mengantisipasi hal tersebut. Beberapa siswa yang tidak memiliki handphone melakukan pembelajaran secara berkelompok, sehingga mereka melakukan aktivitas pembelajaran pun bersama. Mulai belajar melalui videocall yang dihubungkan dengan guru yang bersangkutan, diberi pertanyaan satu persatu, hingga mengabsen melalui VoiceNote yang tersedia di WhatsApp. Materi-materinya pun diberikan dalam bentuk video yang berdurasi kurang dari 2 menit. 
Namun permasalahan yang terjadi di SMP Negeri 1 Gilireng bukan hanya terdapat pada sistem media pembelajaran akan tetapi ketersediaan kuota yang membutuhkan biaya cukup tinggi harganya bagi siswa dan guru guna memfasilitasi kebutuhan pembelajaran daring. Selain itu, koneksi jaringan internet menjadi salah satu kendala yang dihadapi siswa yang tempat tinggalnya sulit untuk mengakses internet, apalagi siswa tersebut tempat tinggalnya di daerah pedesaan, terpencil dan tertinggal. Meskipun ada yang menggunakan jaringan seluler terkadang jaringan yang tidak stabil, karena letak geografis yang masih jauh dari jangkauan sinyal seluler.

Hal yang sama juga diungkapkan oleh Atsani (2020) dalam penelitiannya bahwa sebagian peserta didik tidak dapat mengikuti pembelajaran daring karena ketiadaan sinyal jaringan intenet. Selanjutnya menurut Handayani dan Irawan (2020) keterbatasan infrastruktur penunjang kegiatan pembelajaran daring serta kuota internet yang menyedot cukup banyak menjadi salah satu kesulitan selama pembelajaran daring.

Selain itu, Aboagye, Yawson, dan Appiah (2020) dalam penelitiannya menjelaskan bahwa siswa belum siap dan berpengalaman untuk melakukan pembelajaran daring di masa pandemi ini. Entah siswa merasa takut bahwa mereka akan menghadapi banyak tantangan dengan pembelajaran daring atau mereka berpikir era pandemi adalah waktu untuk berkumpul dengan keluarga.

Meskipun dengan banyaknya kendala yang dihadapi selama pembelajaran daring, tetap guru harus mampu memberikan pembelajaran PPKn dengan metode yang mampu dipahami siswa sehingga pembelajaran yang akan diterima oleh siswa ini dapat efektif agar hasil belajar PPKn siswa dapat maksimal. Aritonang (2008) mengungkapkan bahwa hasil belajar siswa pada hakikatnya adalah perubahan tingkah laku sebagai hasil belajar dalam pengertian yang lebih luas mencakup bidang kognitif, afektif, dan psikomotorik.

Pembelajaran PPKn merupakan salah satu mata pelajaran pokok di sekolah yang bertujuan untuk mengembangkan kecerdasan warga negara dalam dimensi spiritual, rasional, emosional dan sosial, mengembangkan tanggung jawab sebagai warga negara, serta mengembangkan anak didik berpartisipasi sebagai warga negara supaya menjadi warga negara yang baik. Menurut Winataputra, dkk (2009) dalam pembelajaran PPKn, kemampuan menguasai metode pembelajaran merupakan salah satu persyaratan utama yang harus dimiliki guru. Metode yang dipilih dalam pembelajaran PPKn harus disesuaikan dengan karakteristik tujuan pembelajaran PPKn, karakteristik materi pembelajaran PPKn, situasi dan lingkungan belajar siswa, tingkat perkembangan dan kemampuan belajar siswa, waktu yang tersedia dan kebutuhan siswa itu sendiri.

Berdasarkan pemaparan masalah yang terjadi di SMP Negeri 1 Gilireng pada pembelajaran PPKn maka peneliti tertarik untuk melakukan penelitian mengenai efektivitas pembelajaran daring dalam meningkatkan hasil belajar PPKn pada siswa kelas VII SMP Negeri 1 Gilireng.

\section{METODE PENELITIAN}

Jenis penelitian yang digunakan pada penelitian ini adalah jenis penelitian kuantitatif deskriptif. Adapun Populasi dalam penelitian ini yakni seluruh peserta didik di kelas VIIa, VIIb dan VIIc di SMP Negeri 1 Gilireng yang berjumlah 87 peserta didik. 
Sementara itu, jumlah sampel pada penelitian ini sebanyak 43 peserta didik yang terpilih dengan menggunakan teknik pengambilan sampel yakni random sampling.

Sumber data pada penelitian ini terdiri dari dua, yaitu sumber data primer dan sekunder. Adapun instrumen penelitian yang digunakan yaitu: dokumen dan angket (kuesioner). Dokumen-dokumen yang digunakan pada penelitian ini berupa dokumen yang berhubungan dengan kegiatan peserta didik selama melakukan pembelajaran daring yakni absensi dan hasil belajar PPKn. Angket digunakan untuk memperoleh data efektivitas pembelajaran daring yang diungkap melalui pertanyaan tertutup dan terbuka.

Teknik analisis data dalam penelitian ini dilakukan dengan metode kuantitatif deskriptif dengan langkah-langkah, meliputi: (1) Mengkategorikan skor hasil belajar peserta didik menjadi tiga; (2) Membagankan efektivitas pembelajaran daring dalam meningkatkan hasil belajar peserta didik; (3) Memaparkan kendala-kendala yang didahapi selama pembelajaran daring; (4) Menganalisis tiap kelompok kategori efektivitas, dan kendala yang dihadapi selama pembelajaran daring; dan (6) Menyimpulkan hasil analisis data dalam bentuk narasi deskriptif.

\section{HASIL DAN PEMBAHASAN}

Jumlah responden sebanyak 43 peserta didik berjenis kelamin laki laki (26 orang) dan perempuan (17 orang) yang tersebar secara random di tiga kelas (VII A, VIIB, VIIC). Berdasarkan hasil analisis diperoleh gambaran hasil belajar PPKn yang tampak pada gambar 1, dapat diketahui bahwa jumlah peserta didik yang berada pada kategori tinggi sebanyak 7 orang (16 persen), kategori sedang sebanyak 36 orang (84 persen) dan tidak ada ( 0 persen) yang berada pada kategori rendah.

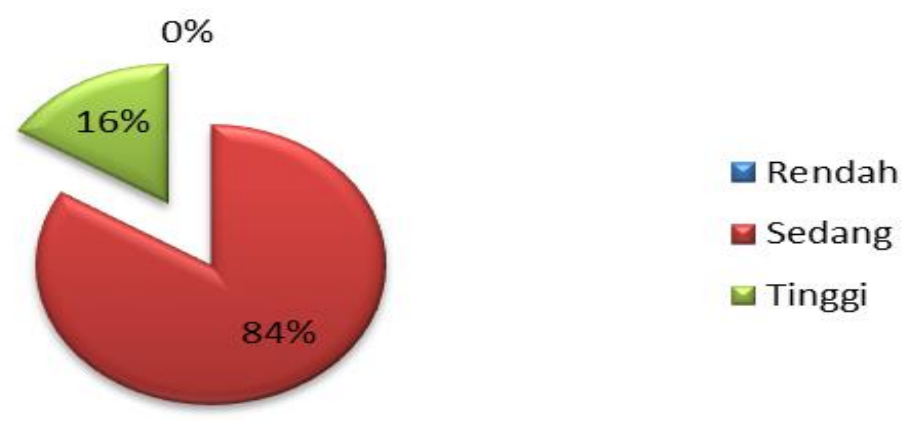

Gambar 1. Hasil Belajar PPKn Peserta Didik

Respon peserta didik bervariasi dalam hal tanggapan tentang efektivitas penyampaian materi yang diberikan oleh guru saat pembelajaran daring. Pada Gambar 2 tampak sebagian besar peserta didik menilai efektivitas penyampaian materi dari guru dengan penilaian efektif (58,1 persen), selanjutnya sangat efektif $(25,6$ persen $)$, ada juga yang menilai kurang efektif ( 14 persen) dan biasa saja ( 7 persen). Tidak ada satupun yang menilai tidak efektif penyampaian materi yang diberikan guru. 


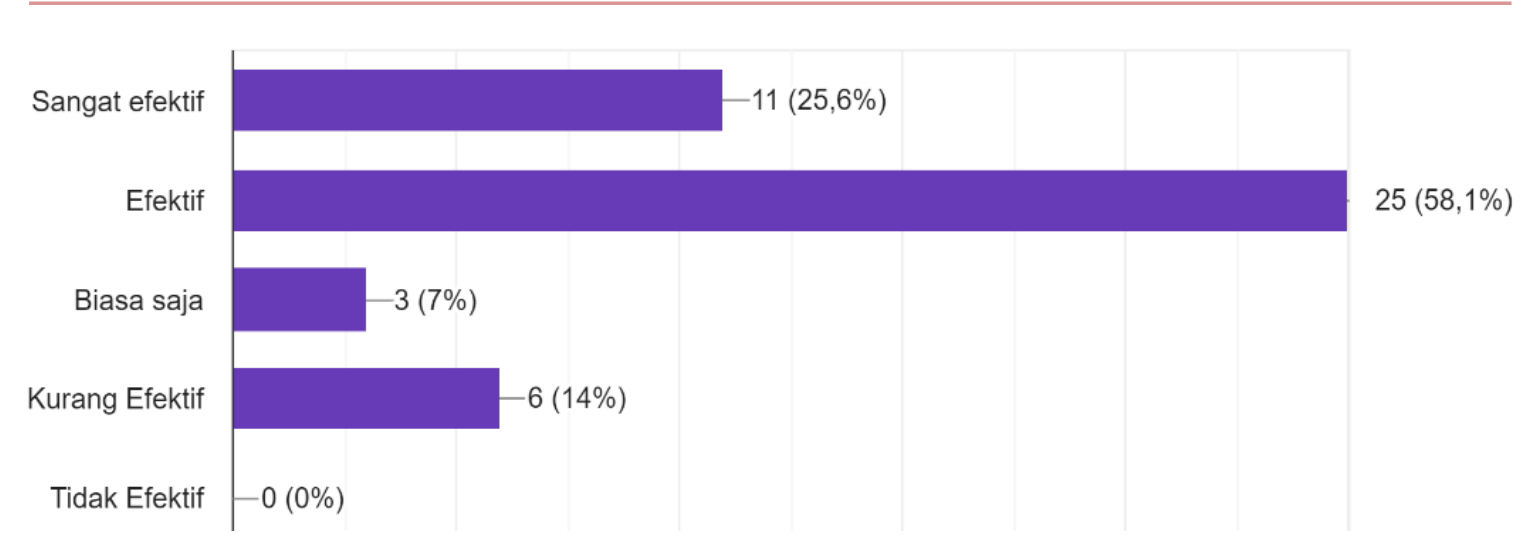

Gambar 2. Efektivitas Penyampaian Materi yang Diberikan oleh Guru

Pembelajaran yang dilakukan seyogianya bertujuan untuk meningkatkan pengetahuan peserta didik. Namun kenyataannya pada Gambar 3 ada juga peserta didik yang menilai bahwa pengetahuan mereka tidak bertambah $(20,9$ persen), ada juga menyatakan mungkin ada peningkatan pengetahuan (39,5 persen), dan sebagian besar menilai terjadi peningkatan pengetahuan selama pembelajaran daring $(41,9$ persen).

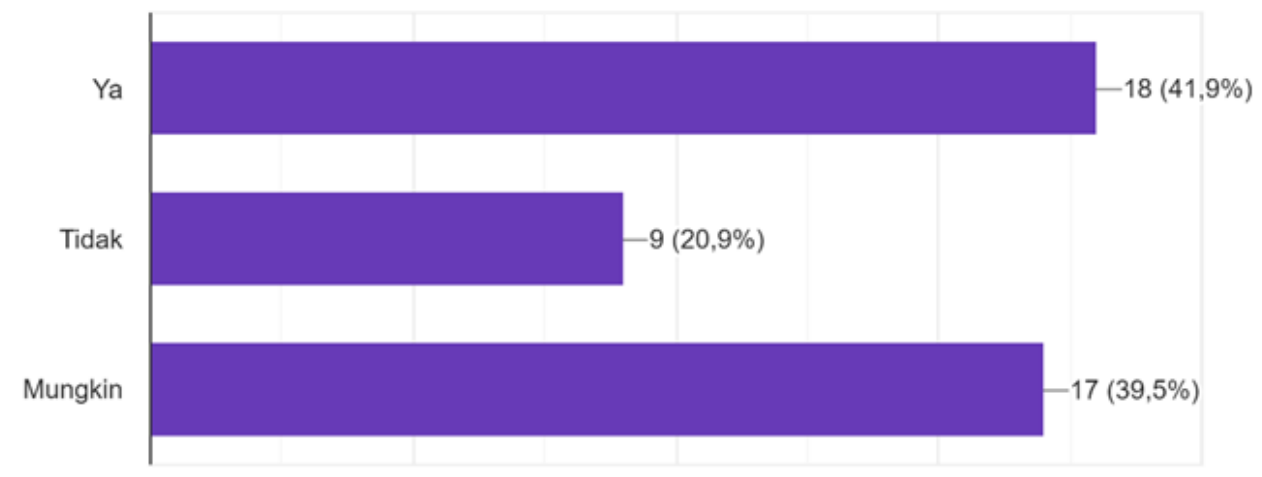

Gambar 3. Peningkatan Pengetahuan selama Pembelajaran Daring

Berdasarkan Gambar 4 dapat diketahui bahwa pembelajaran daring dinilai dapat meningkatkan motivasi belajar peserta didik (37,2 persen), ada juga yang menilai mungkin dapat meningkatkan motivasi belajar (30,2 persen), namun tidak sedikit juga yang menilai bahwa pembelajaran daring tidak meningkatkan motivasi belajar peserta $\operatorname{didik}(32,6$ persen$)$.

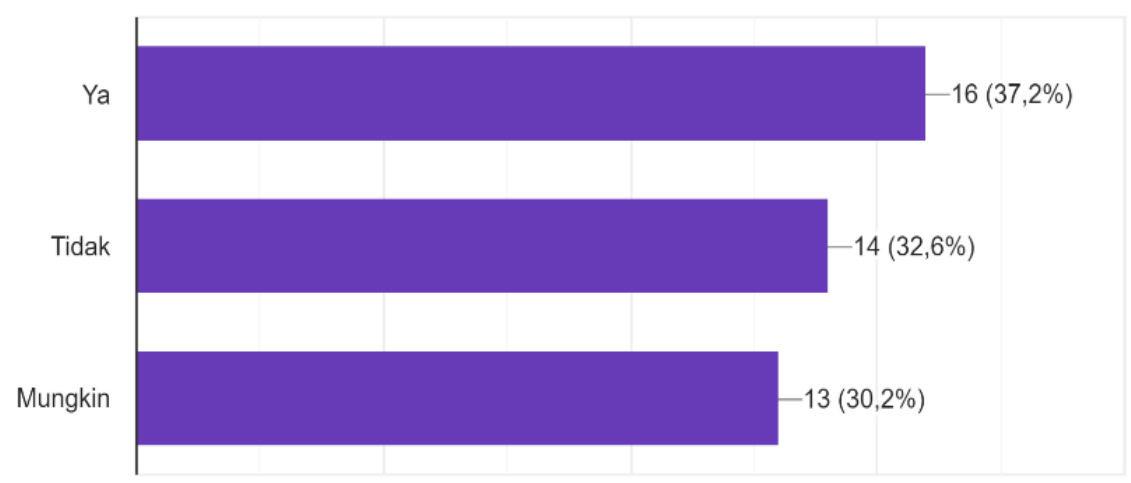

Gambar 4. Motivasi Belajar Selama Pembelajaran Daring 
Aktivitas yang dilakukan oleh peserta didik sangat beragam. Hal tersebut dapat dilihat pada Gambar 5. Aktivitas belajar dengan guru sebagian besar waktu yang digunakan kurang dari 1 jam, waktu untuk mengerjakan tugas sebagian besar dihabiskan 1-2 jam, membaca referensi buku kurang dari 1 jam, waktu untuk membuka media sosial berimbang antara kurang dari 1 jam dan 1-2 jam. Namun ada juga yang menggunakan waktunya dalam bermedia sosial selama 7-8 jam. Waktu yang dihabiskan untuk jalan-jalan terbanyak 3-4 jam. Meskipun paling banyak yang menghabiskan waktu sebanyak 3-4 jam dan lebih dari 8 jam namun ternyata banyak juga yang hanya menggunakan waktu untuk ditidur selama kurang dari 1 jam dan 1-2 jam.

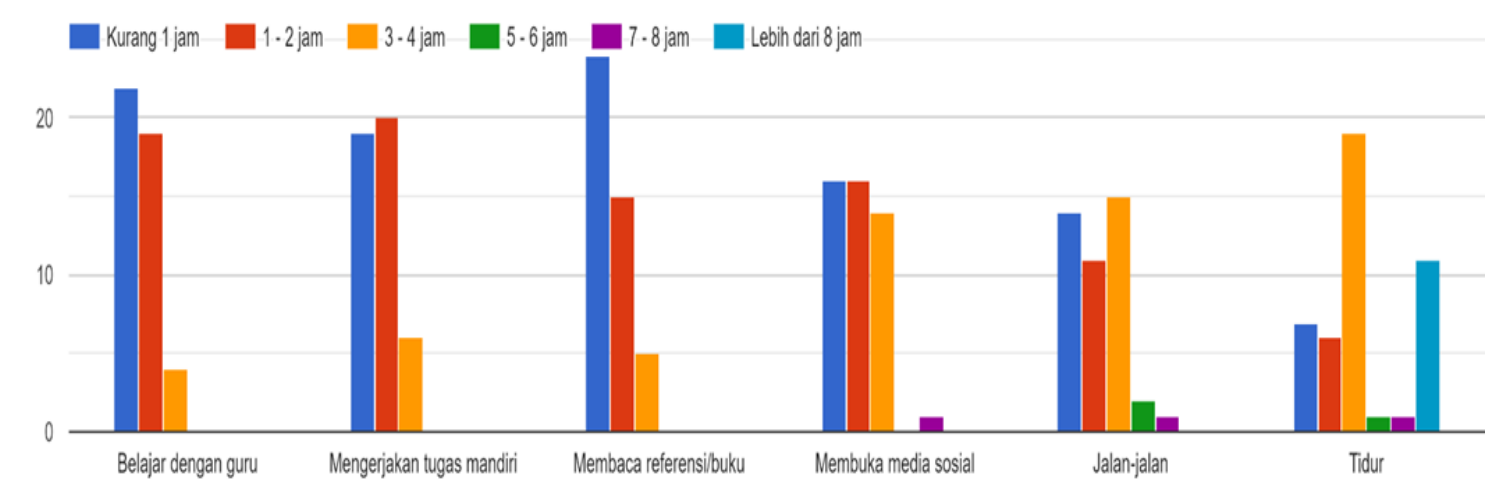

Gambar 5. Jumlah Jam yang Dihabiskan dalam Sehari

Kendala terbesar yang dialami peserta didik selama pembelajaran daring dapat dilihat pada Gambar 6 yang tampak sebagian besar karena jaringan yang buruk $(69,8$ persen), selain itu juga karena kuota yang mahal (34,9 persen). Ternyata kendala pembelajaran daring juga menyebabkan peserta didik tidak bisa fokus karena banyaknya gangguan didapatkan di rumah (20,9 persen). Pembelajaran daring juga tidak memungkinkan peserta didik untuk bekerja sama secara langsung dengan sesame peserta didik (14 persen), serta ada juga peserta didik yang tidak memiliki fasilitas dalam belajar berupa HP android atau laptop.

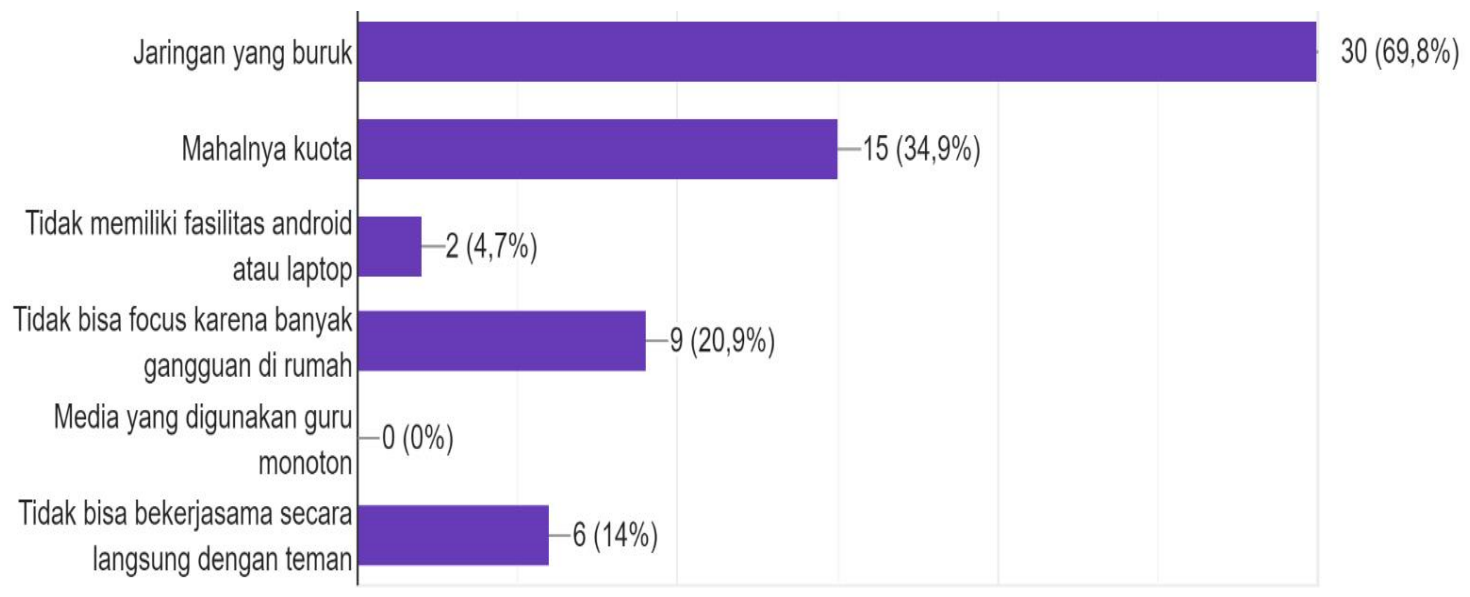

Gambar 6. Kendala yang Dihadapi Selama Pembelajaran Daring 
Sebagian besar peserta didik menilai pembelajaran daring efektif (44,2 persen) untuk meningkatkan hasil belajar, dan ada juga yang menyatakan mungkin (18,6 persen) meningkatkan hasil belajar. Ternyata banyak juga yang menyatakan pembelajaran daring tidak efektif (39,5 persen) dalam meningkatkan hasil belajar peserta didik.

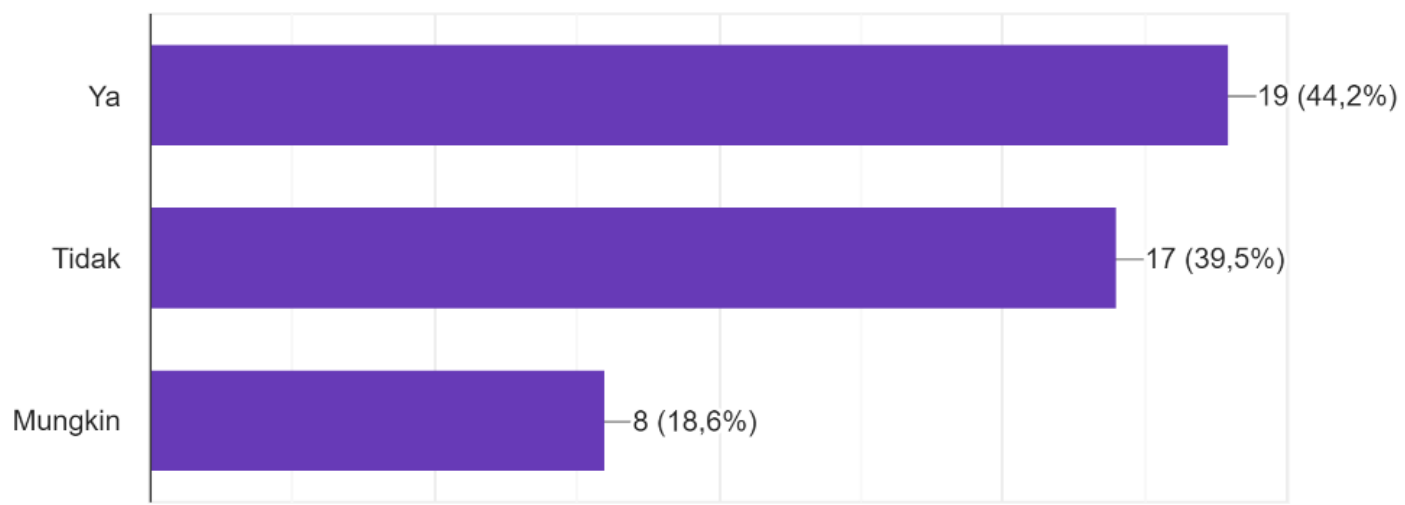

Gambar 7. Efektivitas Pembelajaran Daring

Berdasarkan hasil analisis deskriptif dapat dikategorisasikan efektivitas pembelajaran daring berdasarkan kategorisasi hasil belajar peserta didik yang terlihat pada Tabel 1 menunjukkan bahwa kategori hasil belajar siswa dari 43 siswa, jumlah siswa yang mendapatkan nilai kategori tinggi hanya 7 orang. Dari 7 orang tersebut dapat dilihat yang menilai efektif pembelajaran daring sebanyak 4, namun ada juga yang menilai tidak efektif sebanyak dua dan yang menilai mungkin efektif sebanyak 1 orang. Sementara jumlah siswa dengan hasil belajar yang berada pada kategori sedang sebanyak 37 orang yang memiliki penilaian yang sebanding jumlahnya antara yang menilai efektif dengan tidak efektinya pembelajaran daring yakni masing-masing 15 orang. Selain itu sebanyak 6 orang yang menilai mungkin efektif pembelajaran daring. Sehingga dapat disimpulkan bahwa keefektifan pembelajaran daring biasa saja (antara efektif dengan tidak efektif) dalam meningkatkan hasil belajar peserta didik karena hampir berbanding jumlahnya antara yang menilai efektif dengan tidak efektif pembelajaran daring baik dari hasil belajar kategori sedang maupun tinggi.

Tabel 1. Efektivitas Pembelajaran Daring berdasarkan Kategorisasi Hasil Belajar

\begin{tabular}{llll}
\hline Efektivitas Pembelajaran & \multicolumn{2}{l}{ Kategorisasi Hasil Belajar } & \multirow{2}{*}{ Total } \\
\cline { 2 - 3 } Daring & Sedang & Tinggi & 7 \\
\hline Mungkin & 6 & 1 & 17 \\
Tidak & 15 & 2 & 19 \\
Ya & 15 & 4 & $\mathbf{4 3}$ \\
\hline Total & $\mathbf{3 6}$ & $\mathbf{7}$ & \\
\hline
\end{tabular}

Hasil penelitian ini didukung hasil-hasil penelitian sebelumnya yang menyatakan bahwa pembelajaran daring dapat meningkatkan hasil belajar menggunakan media pembelajaran (Damanti, Suradika, \& Ulfaniatari 2020; Nurhayati, 2020). Pembelajaran daring merupakan pembelajaran yang mampu menjadikan peserta didik mandiri dan 
tidak bergantung dengan orang lain, sebab peserta didik akan lebih fokus pada layar handphone selama pembelajaran berlangsung (Syarifudin, 2020).

Menurut Nugraha, Sudiatmi, dan Suswandari (2020) terdapat pengaruh penggunaan media daring terhadap hasil belajar matematika siswa; pembelajaran menggunakan e-learning madrasah tergolong efektif untuk dilaksanakan (Sutini, Mushofan, Ilmia, Yanti, Rizky, \& Lailiyah, 2020). Pembelajaran daring dapat meningkatkan motivasi belajar siswa melalui dukungan orang tua (Lanes, Warouw, \& Mingkid, 2021), terdapat hubungan positif dan searah antara motivasi belajar dan prestasi belajar (Suharti, Muslim, \& Sriyanto, 2020).

Berdasarkan penelitian yang dilakukan oleh Khusniyah dan Hakim (2019) menunjukkan bahwa ada pengaruh positif dari blog terhadap proses pembelajaran membaca bahasa Inggris sehingga berdampak pula terhadap peningkatan nilai yang diperoleh. Fauziyah (2020) dalam penelitiannya mengenai dampak covid-19 terhadap efektifitas pembelajaran daring pendidikan islam menyatakan bahwa efektivitas pembelajaran daring ini tergantung dari teknologi, pendidik dan peserta didik itu sendiri, sebagai pendidik dan siswa harus memahami teknologi, dan bagi peserta didik juga perlu kepercayaan diri agar dalam melakukan pembelajaran ini selalu semangat dan fokus.

Menurut Dhull dan Sakshi (2017) pembelajaran daring memungkinkan peserta didik memiliki keleluasaan waktu belajar, sehingga mereka dapat belajar kapanpun dan dimanapun. Selanjutnya Dewi (2020) mengungkapkan bahwa pembelajaran daring sebaiknya dilaksanakan sesuai dengan kemampuan masing-masing sekolah.

Akan tetapi hasil penelitian yang dilakukan oleh Alfiyatin (2020) yang mengemukakan bahwa pembelajaran daring tidak efektif karena tidak memenuhi kriteria hasil belajar dan respon siswa yang positif mengenai pembelajaran daring. Perbedaan hasil penelitian ini mungkin disebabkan oleh beberapa kesulitan yang dialami selama pembelajaran daring sebagaimana dipaparkan pada pendahuluan.

Permasalahan yang terjadi dalam proses pembelajaran daring dalam meningkatkan hasil belajar PPKn terdapat pada sistem media pembelajaran yang monoton. Tidak hanya itu, ketersediaan kuota yang membutuhkan biaya cukup tinggi harganya bagi siswa dan guru guna menfasilitasi kebutuhan pembelajaran daring. Kouta yang dibeli untuk kebutuhan internet menjadi melonjak dan banyak di antara orang tua siswa yang tidak siap untuk menambah anggaran dalam menyediakan jaringan internet.

Hal ini pun menjadi permasalahan yang sangat penting bagi siswa, jam berapa mereka harus belajar dan bagaimana data (kouta) yang mereka miliki, sedangkan orangtua mereka hanya berhangsilan rendah atau dari kalangan menengah kebawah (kurang mampu). Hingga akhirnya hal seperti ini dibebankan kepada orang tua siswa yang ingin anaknya tetap mengikuti pembelajaran daring.

Pembelajaran daring tidak bisa terlepas dari jaringan internet. Koneksi jaringan internet menjadi salah satu kendala yang dihadapi siswa karena tempat tinggal di daerah pedesaan. Kalaupun ada yang menggunakan jaringan seluler terkadang jaringan tidak stabil, karena letak geografis yang masih jauh dari jangkauan sinyal seluler. Hal ini menjadi permasalahan yang banyak terjadi pada siswa yang mengikuti pembelajaran dalam penelitian ini sehingga biasa saja efektifnya pembelajaran daring dalam meningkatkan hasil belajar PPKn (bukan sangat efektif dan juga bukan tidak efektif). 
Berdasarkan hasil uraian tersebut, penulis mengklarifikasikan faktor yang mempengaruhi hasil belajar ke dalam dua faktor yaitu, faktor internal dan faktor eksternal. Faktor internal ini merupakan faktor yang berasal dari dalam diri siswa itu sendiri, seperti minat, bakat, dan motivasi, sedangkan faktor eksternal merupakan faktor yang berasal dari luar diri siswa atau berasal dari lingkungan.

Menurut Tauhid, Nurmalasari, Foldra, dan Jayawinangun (2020), pembelajaran daring berdasarkan jenjang pendidikan anak usia dini, sekolah dasar, sekolah menengah dan perguruan tinggi dinilai efektif, namun pada praktiknya masih perlu perbaikan dapat lebih menjadi lebih baik. Selanjutnya hasil penelitian yang dilakukan oleh Mustakim (2020) menunjukkan bahwa bahwa siswa tidak antusias dalam mengikuti pembelajaran daring siswa lebih menyukai pembelajaran tatap muka.

\section{SIMPULAN}

Setelah dilakukan kajian dan penelitian serta pembahasan mengenai efektivitas pembelajaran daring dalam meningkatkan hasil belajar PPKn menunjukkan bahwa kategori hasil belajar siswa dari 43 siswa, jumlah siswa yang mendapatkan nilai kategori tinggi hanya 7 orang yang terbagi yang menilai efektif pembelajaran daring sebanyak 4, namun ada juga yang menilai tidak efektif sebanyak dua dan yang menilai mungkin efektif sebanyak 1 orang. Sementara jumlah siswa dengan hasil belajar yang berada pada kategori sedang sebanyak 37 orang yang memiliki penilaian yang sebanding jumlahnya antara yang menilai efektif dengan tidak efektinya pembelajaran daring yakni masing-masing 15 orang. Selain itu, sebanyak 6 orang yang menilai mungkin efektif pembelajaran daring. Sehingga dapat disimpulkan bahwa keefektifan pembelajaran daring biasa saja (antara efektif dengan tidak efektif) dalam meningkatkan hasil belajar peserta didik karena hampir berbanding jumlahnya antara yang menilai efektif dengan tidak efektif pembelajaran daring baik dari hasil belajar kategori sedang maupun tinggi.

\section{DAFTAR PUSTAKA}

Aboagye, E., Yawson, J. A., \& Appiah, K. N. (2020). COVID-19 and e-learning: the challenges of students in tertiary institutions. Social Education Research, 2(1), 1-8. https://doi.org/10.37256/ser.212021422

Alessandro, B. (2018). Digital skills and competence, and digital and online learning. Turin: European Training Foundation.

Alfiyatin, Y. (2020). Pembelajaran daring dalam pandangan siswa MI Al-Falah DakiringBangkalan. Al-Ibrah: Jurnal Pendidikan Dan Keilmuan Islam, 5(2), 1-22. Retrieved from http://ejournal.stital.ac.id/index.php/alibrah/article/view/105

Aritonang, K. T. (2008). Minat dan motivasi dalam meningkatkan hasil belajar siswa. Jurnal Pendidikan Penabur, 7(10), 11-21.

Atsani, K. L. G. M. Z. (2020). Transformasi media pembelajaran pada masa pandemi covid19. AL-Hikmah: Jurnal Studi Islam, 1(1), 82-93. Retrieved from http://ejournal.kopertais4.or.id/sasambo/index.php/alhikmah/article/view/390 5

Damanti, A., Suradika, A., \& Ulfaniatari. (2020). Upaya peningkatan hasil belajar matematika melalui media infografis pada pembelajaran jarak jauh siswa kelas III 
SDN Pondok Pinang 08 Pagi Jakarta. Prosiding Seminar Nasional Penelitian LPPM UMJ, $\quad 1-11$ Retrieved from https://jurnal.umj.ac.id/index.php/semnaslit/article/view/7856

Dewi, W. A. F. (2020). Dampak covid-19 terhadap implementasi pembelajaran daring di sekolah dasar. Edukatif: Jurnal Ilmu Pendidikan, 2(1), 55-61. https://doi.org/10.31004/edukatif.v2i1.89

Dhull, I., \& Sakshi. (2017). Online learning. International Education \& Research Journal (IERJ), 3(8), 32-34.

Fauziyah, N. (2020). Dampak covid-19 terhadap efektivitas pembelajaran daring pendidikan Islam. Al-Mau'izhoh, 2(2). Retrieved from http://www.jurnal.unma.ac.id/index.php/am/article/view/2294

Fitriyani, Y., Fauzi, I., \& Sari, M. Z. (2020). Motivasi belajar mahasiswa pada pembelajaran daring selama pandemik covid-19. Jurnal Kependidikan : Jurnal Hasil Penelitian Dan Kajian Kepustakaan Di Bidang Pendidikan, Pengajaran, Dan Pembelajaran, 6(2), 165-175. https://doi.org/10.33394/jk.v6i2.2654

Handayani, S. D., \& Irawan, A. (2020). Pembelajaran matematika di masa pandemic covid19 berdasarkan pendekatan matematika realistic. Jurnal Math Educator Nusantara, 6(2), 179-189. https://doi.org/10.29407/jmen.v6i2.14813

Khasanah, D. R. A. U., Pramudibyanto, H., \& Widuroyekt, B. (2020). Pendidikan dalam masa pandemi covid-19. Jurnal Sinestesia, 10(1), 41-48. Retrieved from https://sinestesia.pustaka.my.id/journal/article/view/44

Khusniyah, N. L., \& Hakim, L. (2019). Efektivitas pembelajaran berbasis daring: sebuah bukti pada pembelajaran bahasa inggris. Jurnal Tatsqif, 17(1), 19-33. https://doi.org/10.20414/jtq.v17i1.667

Lanes, L. G., Warouw, D. M. D., \& Mingkid, E. (2021). Peran komunikasi antarpribadi orang tua dalam proses belajar daring bagi anak di SD Negeri 15 Manado. Acta Diurna Komunikasi, 3(1). Retrieved from https://ejournal.unsrat.ac.id/index.php/actadiurnakomunikasi/article/view/320 79

Mustakim. (2020). Efektivitas pembelajaran daring menggunakan media online selama pandemi covid-19 pada mata pelajaran matematika. Al Asma : Journal of Islamic Education, 2(1), 1-12. https://doi.org/10.24252/asma.v2i1.13646

Mustofa, M. I., Chodzirin, M., Sayekti, L., \& Fauzan, R. (2019). Formulasi model perkuliahan daring sebagai upaya menekan disparitas kualitas perguruan tinggi. Walisongo Journal of Information Technology, https://doi.org/10.21580/wjit.2019.1.2.4067

Nugraha, S., Sudiatmi, T., \& Suswandari, M. (2020). Studi pengaruh daring learning terhadap hasil belajar matematika. Jurnal Inovasi Penelitian, 1(3), 265-276. https://doi.org/10.47492/jip.v1i3.74

Nurhayati, E. (2020). Meningkatkan keaktifan siswa dalam pembelajaran daring melalui media game edukasi quiziz pada masa pencegahan penyebaran covid-19. Jurnal Paedagogy: Jurnal Penelitian Dan Pengembangan Pendidikan, 7(3), 145-150. https://doi.org/10.33394/jp.v7i3.2645

Sahu, P. (2020). Closure of universities due to coronavirus disease 2019 (COVID-19): impact on education and mental health of students and academic staff. Cureus, 2019. https://doi.org/10.7759/cureus.7541. 
Suharti, Muslim, A., \& Sriyanto. (2020). Hubungan motivasi belajar dengan prestasi belajar matematika siswa kelas V SD Negeri Daerah Binaan 1 Sumbang Banyumas. Madrasah: Jurnal Pendidikan Dan Pembelajaran Dasar, 3(1), 51-63. https://doi.org/10.18860/mad.v13i1.9662

Sutini, Mushofan, M., Ilmia, A., Yanti, A. D., Rizky, A. N., \& Lailiyah, S. (2020). Efektivitas pembelajaran daring dengan menggunakan e-learning madrasah terhadap optimalisasi pemahaman matematika siswa. RPM (Jurnal Review Pembelajaran Matematika), 5(2), 124-136. https://doi.org/10.15642/jrpm.2020.5.2.124-136

Syarifudin, A. S. (2020). Implementasi pembelajaran daring untuk meningkatkan mutu pendidikan sebagai dampak diterapkannya social distancing. Jurnal Pendidikan Bahasa Dan Sastra Indonesia Metalingua, 5(1), 31-34. https://doi.org/10.21107/metalingua.v5i1.7072

Tauhid, S. M., Nurmalasari, Foldra, F., \& Jayawinangun, R. (2020). Trend kajian pembelajaran daring: suatu telaah pustaka. Jurnal Penelitian Sosial IImu Komunikasi, 4(2), 167-164. Retrieved from https://journal.unpak.ac.id/index.php/apik/article/view/2535

Winataputra., U. S., dkk. (2009). Materidan dan pembelajaran PKn SD. Jakarta: Universitas Terbuka. 